\title{
The role of cytokines and chemokines in Histoplasma capsulatum infection
}

\author{
Danielle N. Kroetz ${ }^{a, 1}$ and George S. Deepe Jr. ${ }^{a, b}$ \\ ${ }^{a}$ Division of Infectious Diseases, University of Cincinnati College of Medicine, Cincinnati, $\mathrm{OH}$ \\ 45267 USA \\ bVeterans Affairs Hospital, Cincinnati, OH 45220 USA
}

\begin{abstract}
Histoplasma capsulatum is a prevalent fungal pathogen in the United States, infecting approximately 500,000 individuals each year. Host protection requires an intact cell-mediated immune response. In this review, we will discuss how cytokines and chemokines influence protective immunity in $H$. capsulatum infection.
\end{abstract}

\section{Keywords}

Fungus; infection; cytokine; chemokine

\section{Introduction}

The dimorphic fungus Histoplasma capsulatum is found worldwide, but is endemic in the Midwest and Southeast regions of the United States. Epidemiological studies have shown that as many as $90 \%$ of individuals in endemic areas have been exposed to H. capsulatum $(1,2)$. The majority of people infected with $H$. capsulatum develop an acute pulmonary infection that is asymptomatic or associated with mild flu-like symptoms, including fever, malaise, headache, and weakness. This self-limiting infection normally occurs in children or individuals exposed to the organism for the first time. However, in immunocompromised individuals, infection with $H$. capsulatum often results in a disseminated infection that is lethal (3). Infection typically occurs upon inhalation of microconidia and mycelial fragments upon disruption of soil containing the organism. Once deposited in the lungs, $H$. capsulatum is internalized by resident and recruited phagocytes, including macrophages $(M \phi)$, dendritic cells (DCs), and neutrophils. The intracellular fate of the organism is divergent in these cellular populations. While neutrophils and DCs have fungistatic and fungicidal activity (47 ), respectively, $H$. capsulatum survives in $M \phi$ prior to cellular activation by regulating the $\mathrm{pH}$ of the intraphagosomal environment (8). Phagocytes facilitate dissemination of $H$. capsulatum to several organs, including the spleen, liver, bone marrow, and lymph nodes. Thus, to control intracellular growth of the organism, the host must mount a robust proinflammatory response. In this review, we will discuss how cytokines and chemokines

\footnotetext{
(C) 2011 Elsevier Ltd. All rights reserved.

${ }^{1}$ Corresponding author: Danielle N. Kroetz, kroetzdn@ucmail.uc.edu, Phone-513-558-4810, Fax-513-558-2089.
}

Publisher's Disclaimer: This is a PDF file of an unedited manuscript that has been accepted for publication. As a service to our customers we are providing this early version of the manuscript. The manuscript will undergo copyediting, typesetting, and review of the resulting proof before it is published in its final citable form. Please note that during the production process errors may be discovered which could affect the content, and all legal disclaimers that apply to the journal pertain. 
interact with host immune cells, trigger or inhibit anti-fungal activity, and ultimately dictate the outcome of infection.

\section{Protective cytokines in $\boldsymbol{H}$. capsulatum infection}

\subsection{Th1 response}

The development of a Th1 immune response is required to successfully control $H$. capsulatum infection (Figure 1). Early production of IL-12 by innate cells is required for the initiation and amplification of a Th1 response. DCs and neutrophils are likely the predominant source of IL-12 since $H$. capsulatum downregulates IL-12 production by $\mathrm{M} \phi$ by binding to the complement receptor 3 (CR3, CD11b/CD18) to gain entry (9). IL-12 stimulates the synthesis of IFN- $\gamma$ by $\mathrm{CD}^{+} \mathrm{T}, \mathrm{CD} 8^{+} \mathrm{T}$ cells, as well as NK cells $(10,11)$. $\mathrm{CD}^{+} \mathrm{T}$ cells are the predominant producers of IFN- $\gamma$ in H. capsulatum infection. Depletion of this population accelerates mortality as a result of defective IFN- $\gamma$ production. Although $\mathrm{CD} 8^{+} \mathrm{T}$ cells contribute to IFN- $\gamma$ in infected lungs, this population appears to simultaneously regulate IFN- $\gamma$ production, preventing immunopathology (12). A major function of IFN- $\gamma$ is the activation of phagocytes at the site of infection. IFN- $\gamma$ inhibits intracellular growth of $H$. capsulatum by stimulating murine $\mathrm{M} \phi$ to produce nitric oxide (NO) $(13,14)$. Another mechanism by which IFN- $\gamma$ controls intracellular replication is by limiting the amount of iron and zinc accessible to H. capsulatum $(15,16)$. Regulation of iron and zinc transporters is likely how IFN- $\gamma$ dictates intracellular metal concentrations. In other models, it has been demonstrated that IFN- $\gamma$ downregulates the transferrin receptor, which limits the amount of iron available to the organism, impairing intracellular replication (17, $18)$.

The proinflammatory cytokine TNF- $\alpha$ is also required for the development of a protective immune response during $H$. capsulatum infection (19). T cells are the predominant source of TNF- $\alpha$ upon infection. Other populations including monocytes, M $\phi$, and DC also contribute to TNF- $\alpha$ production in the lungs $(20,21)$. The use of TNF- $\alpha$ antagonist, including infliximab and etanercept, for the treatment of inflammatory diseases such as rheumatoid arthritis and Crohn's disease can have detrimental consequences if an individual has previously been infected or is subsequently exposed to $H$. capsulatum. Blockade of TNF- $\alpha$ signaling facilitates reactivation $H$. capsulatum or enhances susceptibility to the organism, potentially causing a severe disseminated infection that can ultimately be lethal (22).

During primary infection, TNF- $\alpha$ stimulates NO production to regulate intracellular growth. Additionally, signaling through TNFR1 promotes the influx of immune cells to lungs during infection, as the cellular infiltrate is altered in TNFR $1^{-l-}$ mice. The expression of several chemokines and chemokine receptors is influenced by TNF- $\alpha$. In H. capsulatum infection, chemokine receptors such as CCR2 and CCR5 have been identified as potent mediators of inflammatory cell recruitment to the lungs $(23,24)$. Thus, it seems likely TNF- $\alpha$ indirectly controls cellular migration by controlling chemokine production. TNF- $\alpha$ also controls the secretion of both pro- and anti-inflammatory cytokines in $H$. capsulatum infection. In primary infection, signaling through TNFR2 regulates IFN- $\gamma$ expression, as the concentration of IFN- $\gamma$ is reduced in TNFR $2^{-/-}$lungs. Administration of recombinant IFN- $\gamma$ significantly lowers fungal burden and enhances survival in TNFR2 ${ }^{-/-}$mice. In contrast, IFN- $\gamma$ is elevated in TNFR $1^{-/-}$mice. However, enhanced IFN- $\gamma$ is not sufficient to rescue these animals suggesting TNF- $\alpha$ and IFN- $\gamma$ work in synergy to promote protective immunity. During secondary infection, the anti-inflammatory cytokines IL-4 and IL-10 are upregulated in TNFR $1^{-/-}$mice, dampening the Th1 immune response, resulting in unrestricted fungal growth. 
TNF- $\alpha$ also dictates the immune response to $H$. capsulatum by regulating the emergence of regulatory $\mathrm{T}$ cells (Tregs) and the magnitude of apoptosis $(25,26)$. Administration of a monoclonal antibody to TNF- $\alpha$ results elevates the proportion of Tregs in the lungs during primary and secondary histoplasmosis. Tregs in TNF- $\alpha$-neutralized mice dampen the protective immune response in an IL-10-dependent manner (26). How TNF- $\alpha$ regulates the emergence of this population remains unresolved. One possibility is that TNF- $\alpha$ limits Treg expansion. IL-2, which is involved in the maintenance and expansion of peripheral Tregs (27), is augmented in the lungs after neutralization of TNF- $\alpha$. Thus, TNF- $\alpha$ may dictate Treg expansion by regulating cytokine expression. Alternatively, since TNF- $\alpha$ influences the expression of CCR5 and its ligands, which have been identified as potent mediators of Treg chemotaxis, it is possible trafficking is improved in the absence of TNF- $\alpha$. Additionally, TNF- $\alpha$ signals through TNFR1 to trigger apoptosis in infected lungs. The severity of infection is influenced by the proportion of apoptotic lung leukocytes. Administration of a caspase inhibitor to block apoptosis exacerbates infection in mice. In mice lacking TNF- $\alpha$ or $\mathrm{TNFR}^{-/-}$, diminished apoptosis correlates with elevated fungal burden.

Other Th1-associated cytokines such as granulocyte-macrophage colony-stimulating factor (GM-CSF) and IL-1 $\beta$ influence host protection in H. capsulatum infection. Neutralization of either GM-CSF or IL- $1 \beta$ is associated with an altered cytokine profile and fewer effector T cells in infected lungs. Mice lacking either cytokine have depressed expression of proinflammatory cytokines IFN- $\gamma$ and TNF- $\alpha$, which correlates with diminished NO production. In contrast, production of cytokines with anti-inflammatory roles, including IL-4 and IL-10, are elevated in GM-CSF-neutralized and IL-1 $\mathrm{R}^{-/-}$mice infected with $H$. capsulatum. These alterations in cytokine expression increase the severity of infection and cause a significant proportion of animals to succumb to infection $(28,29)$. Furthermore, it is possible that the Th17 response is dampened since signaling through IL-1R has been implicated in the induction of Th17 cells (30). However, it seems unlikely that depressed IL-17 production in the absence of IL-1 signaling would contribute to the lethal outcome since IL-17 plays only a minor role in controlling $H$. capsulatum infection.

GM-CSF, along with M-CSF and IL-3, stimulates M $\phi$ fungistatic activity against $H$. capsulatum yeast (31). One mechanism by which GM-CSF controls intracellular growth is by regulating $M \phi$ metal levels (16). Metallomic analysis of infected $M \phi$ revealed a fundamental role for zinc in response to $H$. capsulatum. Treatment with a zinc chelator inhibits both extracellular and intracellular yeast replication. Upon activation of $M \phi$ with GM-CSF, the amount of zinc, as well as iron available to the organism is diminished. Additionally, a reduced amount of intracellular zinc after activation with GM-CSF is accompanied by alterations in the zinc binding species profile. IL-4, which promotes the growth of $H$. capsulatum in $\mathrm{M} \phi$, elevates intracellular zinc and reverses the anti-fungal activity of GM-CSF.

\subsection{Th17 response}

The significance of a Th17 response in controlling $H$. capsulatum infection was recently elucidated $(24,32)$. Th17 cells are a distinct subset of $\mathrm{T}$ cells that arise from naïve $\mathrm{T}$ cells in the presence of IL- 6 and TGF- $\beta$ and require the transcription factor retinoic acid receptorrelated orphan receptor $\gamma \mathrm{t}$ (33). Although their name originates from their ability to secrete IL-17, other cytokines, including IL-21, IL-22, TNF- $\alpha$, and IL-6, are also released from these cells (34). IL-17 promotes the production of proinflammatory cytokines, including TNF- $\alpha$ and IL-1 $\beta$, as well CXC chemokines involved in recruitment and activation of M $\phi$ and neutrophils in several models of infection $(35,36)$. Others, however, have identified a negative role for IL-17 during fungal infection. In Aspergillus fumigatus infection, IL-23deficient mice are less susceptible to infection as a result of increased IL-12 and IFN- $\gamma$ 
production (37). In these models, the presence of IL-23 and IL-17 suppress the Th1mediated immune response and the fungicidal activity of neutrophils.

In $H$. capsulatum infection, initial studies identified IL-17 in hepatic granulomas (38). Subsequent studies demonstrated that the concentration of cytokines associated with a Th17 response including IL-6, IL-23, and IL-17 gradually increase the first week of infection and declines thereafter in pulmonary histoplasmosis. $\mathrm{CD}^{+}$and $\mathrm{CD}^{+} \mathrm{T}$ cells expressing $\mathrm{CD} 25$ are the predominant source of IL-17 during infection. Although IL-6 is considered to be critical in the generation of Th17 cells, the proportion and number of IL-17 ${ }^{+}$cells is unaltered in IL- $6^{-1-}$ mice during infection (32). IL-21 in synergy with TGF- $\beta$ can induce an alternative pathway of Th17 generation (39). Thus, it is possible that IL-21 rather than IL-6 promotes Th17 in $H$. capsulatum infection. IL-17 mediates the influx of inflammatory cells to the lungs during infection; however, plays a minimal role in host protection to primary and secondary infection. Mice lacking endogenous IL-17 resolve infection despite manifesting a modest elevation in fungal burden at day 7 post-infection. Interestingly, in the absence of IL-12, IL-23 promotes the development of a protective Th17 response. IL-12p35 $1-1-$ mice, which lack IL-12, have prolonged survival compared to IL-12p40-/mice, which lack both IL-12 and IL-23. Enhanced survival of IL-12p35 observed after treatment with anti-IL-17, highlighting the significance of the Th17 response in protective immunity if the Th1 response is compromised (32). In contrast, a vital role for Th17 cells in vaccine-mediated resistance to several fungi including $H$. capsulatum has been described. Signaling through IL-17RA controls fungal resolution by promoting the homing and effector function of neutrophils and $\mathrm{M} \phi$ after challenge in vaccinated mice (40).

\section{Exacerbating cytokines in $\boldsymbol{H}$. capsulatum infection}

Cytokines with anti-inflammatory functions such as IL-4 and IL-10 are important for controlling the proinflammatory response associated with $H$. capsulatum infection $(41,42)$. IL-10 is a pleiotropic cytokine that is produced by phagocytes and T cells in response to $H$. capsulatum. In both primary and secondary infection, clearance of $H$. capsulatum from the lungs and spleen is accelerated in the absence of endogenous IL-10. Enhanced production of protective cytokines, including IFN- $\gamma$ and GM-CSF, likely facilitate clearance in IL-10 ${ }^{-/-}$ mice. Despite elevation of Th1 cytokines, animals do not display immunopathology in the absence of endogenous IL-10. These data suggest other cytokines or regulatory populations function to limit the Th1 response and ultimately, prevent immune mediated-tissue damage.

In addition to dampening the protective Th1 response, IL-4 impairs fungal resolution by promoting a Th2 response. A dominant Th2 response delays fungal clearance from the lungs and spleen; however, does not prevent animals from resolving infection $(41,43)$. Interestingly, an amplified IL-4 response in $H$. capsulatum infection is not associated with characteristic features such as goblet cell hyperplasia or increased mucus production that is observed in allergy models. IL-4 activates M $\phi$ to have an alternative phenotype which is permissive to fungal growth. IL-4 can promote survival of intracellular pathogens by reducing NO production (44). Additionally, IL-4 is known to dictate the intracellular concentration of metals including calcium, iron, and zinc in $\mathrm{M} \phi(16,45,46)$. In response to $H$. capsulatum, zinc and calcium are elevated in IL-4-activated M $\phi$. IL-4-driven regulation of intracellular zinc controls yeast replication. A higher concentration of zinc after IL-4 treatment partially restores fungal growth (16). Additionally, IFN- $\beta$, which is produced by $\mathrm{M} \phi$ in response to $H$. capsulatum conidia, has been shown to dampen immunity during infection. Mice lacking the type I IFN receptor IFNAR1 have a reduced fungal burden in the lungs and spleen (47). 
Although anti-inflammatory cytokines may depress the protective immune response, their function may be important in controlling particular pathological conditions associated with infection. Syndromes such as mediastinal fibrosis, pericarditis, or presumed ocular histoplasmosis result from an overly exuberant host response rather than uncontrolled infection (48). The driving forces that propel these hyperinflammatory responses have not been identified largely because a suitable animal model has not been developed. But, it is quite likely that a Th1 and/or Th17 response provokes the immune pathology. In these clinical conditions, anti-inflammatory cytokines do not appear to functioning optimally to suppress the mobilization of inflammation. IL-10 and other anti-inflammatory mediators would subserve a highly useful function in these uncommon but devastating forms of histoplasmosis.

\section{The role of chemokines in host protection against $\boldsymbol{H}$. capsulatum}

Although the roles of several proinflammatory cytokines have been extensively characterized in $H$. capsulatum infection, the role of chemokines remains unresolved. Chemokines, a family of chemotactic cytokines, are small proteins (8 to $12-\mathrm{kDa}$ ) that are most notably known for their ability to mediate leukocyte migration and activation (49). The chemokine superfamily is divided into subfamilies based on the spacing between conserved cysteine residues in their $\mathrm{N}$-terminal domain and are classified as $\mathrm{CXC}(\alpha), \mathrm{CC}(\beta), \mathrm{C}(\gamma)$, and $\mathrm{CX}_{3} \mathrm{C}(\delta)$ chemokines (50). Chemokines induce a complex signaling cascade upon binding to pertussis toxin-sensitive $\mathrm{G}$ protein-coupled receptors expressed on the surface of a variety of cell types. Chemokines can also interact with glycosaminoglycans on endothelial surfaces and extracellular matrix to facilitate chemotaxis by establishing a chemokine gradient (51). In addition to promoting chemotaxis, specific chemokines have been shown to activate leukocytes, induce cytokine production, promote $\mathrm{T}$ cell differentiation and polarization, and regulate apoptosis $(52,53)$.

\subsection{CCR5}

The influx of inflammatory cells to the site of $H$. capsulatum infection is associated with the upregulation of multiple chemokines and chemokine receptors. CCR5, which serves as a receptor for CCL3, CCL4, and CCL5, is expressed on both hemopoietic and nonhemopoietic cells and is differentially regulated by pro- and anti-inflammatory cytokines, including IL-12, IFN- $\gamma$, and TNF- $\alpha$ and IL-4 and IL-10, respectively (54). In a peritoneal cavity model of infection, $H$. capsulatum rapidly induces the expression of CCL3. Injection of live $H$. capsulatum, but not $\beta$-glucan isolated from the cell wall, promotes CCL3 production as early as 4 hours after infection (55). Consistently, high concentrations of CCL3 and CCL4 are detected in the lungs by day 3 post-infection in a model of pulmonary histoplasmosis. In contrast, CCL5, which also signals through CCR5, is not upregulated until one week after infection, suggesting it is not required for the influx of innate cells to the lungs.

Signaling through CCR5 promotes the migration of several inflammatory cell populations, including neutrophils, $\mathrm{M} \phi$, DCs, NK cells, and $\mathrm{CD}^{+} \mathrm{T}$ cells, to the lungs after $H$. capsulatum infection. A reduced proportion and absolute number of each of these populations in mice deficient for CCR5 or given a neutralizing antibody to CCL4 enhances the severity of infection during the innate response. However, CCR5 is not required for fungal resolution. The absence of this CCR5 signaling in the adaptive response promotes accelerated clearance due to defective emergence of Tregs. The involvement of CCR5 in Treg recruitment has been characterized during infection with several pathogens $(24,56$, 57). $\mathrm{CD} 4{ }^{+} \mathrm{CD} 25^{+} \mathrm{T}$ cells express high levels of CCR5 and are chemotactic towards CCL3, CCL4, and CCL5. CCL4, which signals exclusively via CCR5, is the most potent chemoattractant for Tregs currently known (58). In H. capsulatum infection, fewer Tregs in 
$\mathrm{CCR5}^{-1-}$ lungs stems from a defect in trafficking, as well as local expansion in the lungs $(24,59)$. Although a reduction in Tregs is associated with an amplified Th1 response in other models, CCR5 ${ }^{-1-}$ mice infected with $H$. capsulatum manifest an enhanced Th17 response which accelerates fungal clearance (Figure 2).

CCR5 likely controls the Treg-Th17 equilibrium by regulating the local cytokine environment. An amplified Th17 response in $\mathrm{CCR}^{-1-}$ mice is also associated with enhanced production of IL-6 and IL-23. IL-6, in synergy with TGF- $\beta$, promotes CD4 ${ }^{+} \mathrm{T}$ cells to commit to the Th17 lineage and inhibits Foxp3 expression/Treg development (60), while IL-23 is involved with Th17 maintenance (61). The paucity of Tregs in CCR $5^{-1-}$ mice correlates with a higher concentration of IL-17 in the lungs. Remarkably, neutralization of IL-17 restores the number of Tregs in CCR $5^{-1-}$ lungs during $H$. capsulatum infection and Treg proliferation is augmented by nearly 3 -fold. These data identifies a potential role for IL-17 in regulating the generation and/or homing of Tregs and consequently, the Treg-Th17 balance. The ability of IL-17 to directly hinder Treg emergence has not been described. Although the aforementioned is a possibility, it seems more likely that this observation is an indirect effect of IL-17. In CCR $5^{-1-}$ mice given anti-IL-17, the concentration of cytokines involved in Treg development and/or function, including IL-2, IL-10, and TGF- $\beta$, are elevated in the lungs. Thus, we postulate these cytokines regulate the emergence of Tregs rather than IL-17 itself. Furthermore, since IL-17 regulates the expression of several chemokines, the possibility of IL-17 regulating Treg chemotaxis should be explored.

H. capsulatum infection results in mild to moderate multifocal peribronchiolar and perivascular mixed inflammatory cuffing in wild-type and CCR $5^{-1-}$ lungs. Coincident with fungal resolution, IL-6, IL-17, IL-22, and IL-23 are restored to wild-type levels by day 21 or earlier, suggesting that elevated Th17 cytokine production is transient, reducing the potential of detrimental inflammation in $\mathrm{CCR}^{-/-}$mice. However, the mechanism by which inflammation is regulated is unresolved. One possibility is that anti-inflammatory cytokines prevent hyper-inflammation in CCR5 ${ }^{-/}$mice. IL-27 and IL-35 are members of the IL-12 family and are heterodimeric proteins composed of Ebi3 (Epstein-Barr virus-induced gene 3 ) and p28 or p35, respectively $(62,63)$. IL-27 is predominantly produced by antigenpresenting cells, whereas IL-35 is produced by Tregs. Since both cytokines have been shown to regulate the Th17 response $(64,65)$, it is plausible that IL-27 and/or IL-35 dampen the Th17 response and restore the Treg-Th17 equilibrium in the absence of CCR5.

\subsection{CCR2}

It addition to CCR5, CCR2 and its ligands influence inflammatory cell recruitment and cytokine production during infection. In the absence of CCR2, mice succumb to infection due to the inability to control $H$. capsulatum infection. A dampened protective immune response in CCR $2^{-/-}$mice is associated with fewer inflammatory cells and elevated IL-4 in the lungs (23). In contrast to other models, amplified IL-4 production does not dampen the expression of Th1 cytokines such IFN- $\gamma$ and TNF- $\alpha$. Although CD4 ${ }^{+} \mathrm{T}$ cells are the predominant source of IL-4 in $H$. capsulatum infection, other cellular populations produce this Th2 cytokine. In the absence of CCR2, an enhanced proportion of $\mathrm{M} \phi$ and DC secrete IL-4 during infection. The negative consequences associated with excess production of IL-4 can be reversed by neutralizing IL-4. Administration of an antibody to IL-4 rescues $\mathrm{CCR} 2^{-/-}$mice; however, does not restore inflammatory cell infiltration.

CCL2 and CCL7 are the CCR2 ligands that signal through CCR2 to regulate IL-4 expression. The absence of CCR2 is associated with elevated IL-4 transcript and protein during the first week of infection. A comparable increase in IL-4 is observed when CCL2 $2^{-1-}$ mice are given a neutralizing antibody to CCL7. Together, CCL2 and CCL7 promote the migration of $\mathrm{CD}^{-}$conventional DCs to the lungs, as this population is diminished in 
CCR2 $2^{-/-}$and CCL7-neutralized CCL2 $2^{-/-}$mice. Adoptive transfer of antigen-specific DC suppresses IL-4 production in CCR2 ${ }^{-1-}$ mice. These results indicate CCR2-dependent recruitment of DCs suppresses local IL-4 production in the lungs. However, although IL-4 levels are restored, $\mathrm{CCR} 2^{-/-}$animals still succumb to infection suggesting other factors regulate fungal clearance in the absence of CCR2.

Enhanced IL-4 skews the immunity to a Th2 response. Since cytokines such as IL-25, IL-33, and TSLP are known to initiate and amply the Th2 response, it is possible CCR2 signaling regulates their expression. The presence of IL-4 is detrimental in H. capsulatum infection because it activates $M \phi$ to have an alternative phenotype. This $M \phi$ population is characterized by augmented expression of Arg1, which is disadvantageous for fungal clearance. Administration of an Arg1 inhibitor modestly reduces fungal burden, but does not enhance survival of CCR2 $2^{-/-}$mice. These data suggest IL-4 dictates fungal resolution in an Arg1-independent manner as well.

\section{Conclusions}

Cytokines and chemokines exert a pivotal role in dictating the outcome of $H$. capsulatum infection. The outcome of infection is largely determined by the early response to invasion. Dissecting the influence and interactions among the various soluble mediators will provide information on why and how the host fails to contain infection. This knowledge can be utilized to create therapeutic agents that transform the response from one that is ineffective to one that can constrain the progressive nature of invasion. The paradigms that arise from work with this intracellular fungal pathogen may extend to a numerous other intracellular microbes.

\section{Highlights}

- The involvement of Th1 and Th17 cytokines in mediating a protective immune response to $H$. capsulatum.

- How cytokines such as IL-4 and IL-10 dampen protective immunity in $H$. capsulatum infection.

- The role of chemokines in the recruitment of immune cells and regulation of cytokine production.

\section{Acknowledgments}

This work was supported by NIH grants AI-073337, AI-083313, AI-094971, and AI-096823 from the National Institutes of Health and 1BX000717 from the Veterans Affairs Administration.

\section{References}

1. Woods JP. Knocking on the right door and making a comfortable home: Histoplasma capsulatum intracellular pathogenesis. Curr Opin Microbiol. 2003; 6:327-331. [PubMed: 12941399]

2. Deepe, GS.; Bullock, WE. Histoplasmosis: a granulomatous inflammatory response. Chap. 40. In: Gallin, JJ.; Goldstein, IM.; Snyder, R., editors. Basic Principles and Clinical Correlates. New York: Raven Press, Ltd; 1988. p. 733-749.

3. Kauffman CA. Histoplasmosis: a clinical and laboratory update. Clin Microbiol Rev. 2007; 20:115132. [PubMed: 17223625]

4. Gildea LA, Morris RE, Newman SL. Histoplasma capsulatum yeasts are phagocytosed via very late antigen-5, killed, and processed for antigen presentation by human dendritic cells. J Immunol. 2001; 166:1049-1056. [PubMed: 11145684] 
5. Brummer E, Kurita N, Yosihida S, Nishimura K, Miyaji M. Fungistatic activity of human neutrophils against Histoplasma capsulatum: correlation with phagocytosis. J Infect Dis. 1991; 164:158-162. [PubMed: 2056203]

6. Kurita N, Brummer E, Yoshida S, Nishimura K, Miyaji M. Antifungal activity of murine polymorphonuclear neutrophils against Histoplasma capsulatum. J Med Vet Mycol. 1991; 29:133143. [PubMed: 1890560]

7. Newman SL, Gootee L, Gabay JE. Human neutrophil-mediated fungistasis against Histoplasma capsulatum. Localization of fungistatic activity to the azurophil granules. J Clin Invest. 1993; 92:624-631. [PubMed: 8349801]

8. Strasser JE, Newman SL, Ciraolo GM, Morris RE, Howell ML, Dean GE. Regulation of the macrophage vacuolar ATPase and phagosome-lysosome fusion by Histoplasma capsulatum. J Immunol. 1999; 162:6148-6154. [PubMed: 10229858]

9. Marth T, Kelsall BL. Regulation of interleukin-12 by complement receptor 3 signaling. J Exp Med. 1997; 185:1987-1995. [PubMed: 9166428]

10. Zhou P, Sieve MC, Bennett J, Kwon-Chung KJ, Tewari RP, Gazzinelli RT, Sher A, Seder RA. IL-12 prevents mortality in mice infected with Histoplasma capsulatum through induction of IFN$\gamma$. J Immunol. 1995; 155:785-795. [PubMed: 7608555]

11. Cain JA, Deepe GS Jr. Evolution of the primary immune response to Histoplasma capsulatum in murine lung. Infect Immun. 1998; 66:1473-1481. [PubMed: 9529070]

12. Allendorfer R, Brunner GD, Deepe GS Jr. Complex requirements for nascent and memory immunity in pulmonary histoplasmosis. J Immunol. 1999; 162:7389-7396. [PubMed: 10358191]

13. Lane TE, Otero GC, Wu-Hsieh BA, Howard DH. Expression of inducible nitric oxide synthase by stimulated macrophages correlates with their antihistoplasma activity. Infect Immun. 1994; 62:1478-1479. [PubMed: 7510670]

14. Nakamura LT, Wu-Hsieh BA, Howard DH. Recombinant murine gamma interferon stimulates macrophages of the RAW cell line to inhibit intracellular growth of Histoplasma capsulatum. Infect Immun. 1994; 62:680-684. [PubMed: 8300224]

15. Lane TE, Wu-Hsieh BA, Howard DH. Iron limitation and the gamma interferon-mediated antihistoplasma state of murine macrophages. Infect Immun. 1991; 59:2274-2278. [PubMed: 1904840]

16. Winters MS, Chan Q, Caruso JA, Deepe GS Jr. Metallomic analysis of macrophages infected with Histoplasma capsulatum reveals a fundamental role for zinc in host defenses. J Infect Dis. 2010; 202:1136-1145. [PubMed: 20731582]

17. Byrd TF, Horwitz MA. Interferon gamma-activated human monocytes downregulate transferrin receptors and inhibit the intracellular multiplication of Legionella pneumophila by limiting the availability of iron. J Clin Invest. 1989; 83:1457-1465. [PubMed: 2496141]

18. Nairz M, Fritsche G, Brunner P, Talasz H, Hantke K, Weiss G. Interferon-gamma limits the availability of iron for intramacrophage Salmonella typhimurium. Eur J Immunol. 2008; 38:19231936. [PubMed: 18581323]

19. Allendoerfer R, Deepe GS Jr. Blockade of endogenous TNF-alpha exacerbates primary and secondary pulmonary histoplasmosis by differential mechanisms. J Immunol. 1998; 160:60726082. [PubMed: 9637524]

20. Deepe GS Jr, Gibbons RS. T cells require tumor necrosis factor- $\alpha$ to provide protective immunity in mice infected with Histoplasma capsulatum. J Infect Dis. 2006; 193:322-330. [PubMed: 16362898]

21. Smith JG, Magee DM, Williams DM, Graybill JR. Tumor necrosis factor-alpha plays a role in host defense against Histoplasma capsulatum. J Infect Dis. 1990; 162:1349-1353. [PubMed: 2230264]

22. Wood KL, Hage CA, Knox KS, Kleiman MB, Sannuti A, Day RB, Wheat LJ, Twigg HL 3rd. Histoplasmosis after treatment with anti-tumor necrosis factor-alpha therapy. Am J Respir Crit Care Med. 2003; 167:1279-1282. [PubMed: 12615627]

23. Szymczak WA, Deepe GS Jr. The CCL7-CCL2-CCR2 axis regulates IL-4 production in lungs and fungal immunity. J Immunol. 2009; 183:1964-1974. [PubMed: 19587014] 
24. Kroetz DN, Deepe GS Jr. CCR5 dictates the equilibrium of proinflammatory $\mathrm{IL}-17^{+}$and regulatory Foxp $3^{+}$T cells in fungal infection. J Immunol. 2010; 184:5224-5231. [PubMed: 20335531]

25. Allen HL, Deepe GS Jr. Apoptosis modulates protective immunity to the pathogenic fungus Histoplasma capsulatum. J Clin Invest. 2005; 115:2875-2885. [PubMed: 16151533]

26. Deepe GS Jr, Gibbons RS. TNF- $\alpha$ antagonism generates a population of antigen-specific $\mathrm{CD} 4{ }^{+} \mathrm{CD} 25^{+} \mathrm{T}$ cells that inhibit protective immunity in murine histoplasmosis. J Immunol. 2008; 180:1088-1097. [PubMed: 18178849]

27. Malek TR, Yu A, Vincek V, Scibelli P, Kong L. CD4 regulatory T cells prevent lethal autoimmunity in IL-2Rbeta-deficient mice. Implications for the nonredundant function of IL-2. Immunity. 2002; 17:167-178. [PubMed: 12196288]

28. Deepe GS Jr, Gibbons R, Woodward E. Neutralization of endogenous granulocyte-macrophage colony-stimulating factor subverts the protective immune response to Histoplasma capsulatum. J Immunol. 1999; 163:4985-4993. [PubMed: 10528203]

29. Deepe GS Jr, McGuinness M. Interleukin-1 and host control of pulmonary histoplasmosis. J Infect Dis. 2006; 194:855-864. [PubMed: 16941354]

30. Sutton C, Brereton C, Keogh B, Mills KH, Lavelle EC. A crucial role for interleukin (IL)-1 in the induction of IL-17-producing T cells that mediate autoimmune encephalomyelitis. J Exp Med. 2006; 203:1685-1691. [PubMed: 16818675]

31. Newman SL, Gootee L. Colony-stimulating factors activate human macrophages to inhibit intracellular growth of Histoplasma capsulatum yeasts. Infect Immun. 1992; 60:4593-4597. [PubMed: 1398972]

32. Deepe GS Jr, Gibbons RS. Interleukins 17 and 23 influence the host response to Histoplasma capsulatum. J Infect Dis. 2009; 200:142-151. [PubMed: 19469707]

33. Ivanov II, McKenzie BS, Zhou L, Tadokoro CE, Lepelley A, Lafaille JJ, Cua DJ, Littman DR. The orphan nuclear receptor ROR $\gamma \mathrm{t}$ directs the differentiation program of proinflammatory $\mathrm{IL}-17^{+} \mathrm{T}$ helper cells. Cell. 2006; 126:1121-1133. [PubMed: 16990136]

34. Zhou L, Ivanov II, Spolski R, Min R, Shenderov K, Egawa T, Levy DE, Leonard WJ, Littman DR. IL-6 programs Th-17 cell differentiation by promoting sequential engagement of the IL-21 and IL-23 pathways. Nat Immunol. 2007; 8:967-974. [PubMed: 17581537]

35. Kleinschek MA, Muller U, Brodie SJ, Stenzel W, Kohler G, Blumenschein WM, Straubinger RK, McClanahan T, Kastelein RA, Alber G. IL-23 enhances the inflammatory cell response in Cryptococcus neoformans infection and induces a cytokine pattern distinct from IL-12. J. Immunol. 2006; 176:1098-1106. [PubMed: 16393998]

36. Huang W, Na L, Fidel PL, Schwarzenberger P. Requirement of interleukin-17A for systemic antiCandida albicans host defense in mice. J Infect Dis. 2004; 190:624-631. [PubMed: 15243941]

37. Zelante T, De Luca A, Bonifazi P, Montagnoli C, Bozza S, Moretti S, Belladonna ML, Vacca C, Conte C, Mosci P, Bistoni F, Puccetti P, Kastelein RA, Kopf M, Romani L. IL-23 and the Th17 pathway promote inflammation and impair antifungal immune resistance. Eur J Immunol. 2007; 37:2695-2706. [PubMed: 17899546]

38. Heninger E, Hogan LH, Karman J, Macvilay S, Hill B, Woods JP, Sandor M. Characterization of the Histoplasma capsulatum-Induced granuloma. J Immunol. 2006; 177:3303-3313. [PubMed: 16920971]

39. Korn T, Bettelli E, Gao W, Awasthi A, Jager A, Strom TB, Oukka M, Kuchroo VK. IL-21 initiates an alternative pathway to induce proinflammatory Th17 cells. Nature. 2007; 448:484-487. [PubMed: 17581588]

40. Wuthrich M, Gern B, Hung CY, Ersland K, Rocco N, Pick-Jacobs J, Galles K, Filutowicz H, Warner T, Evans M, Cole G, Klein B. Vaccine-induced protection against 3 systemic mycoses endemic to North America requires Th17 cells in mice. J Clin Invest. 2011; 121:554-568. [PubMed: 21206087]

41. Peng JK, Lin JS, Kung JT, Finkelman FD, Wu-Hsieh BA. The combined effect of IL-4 and IL-10 suppresses the generation of, but does not change the polarity of, type-1 T cells in Histoplasma infection. Int Immunol. 2005; 17:193-205. [PubMed: 15642955] 
42. Deepe GS Jr, Gibbons RS. Protective and memory immunity to Histoplasma capsulatum in the absence of IL-10. J Immunol. 2003; 171:5353-5362. [PubMed: 14607938]

43. Gildea LA, Gibbons R, Finkelman FD, Deepe GS Jr. Overexpression of interleukin-4 in lungs of mice impairs elimination of Histoplasma capsulatum. Infect Immun. 2003; 71:3787-3793. [PubMed: 12819061]

44. Rutschman R, Lang R, Hesse M, Ihle JN, Wynn TA, Murray PJ. Cutting edge: Stat6-dependent substrate depletion regulates nitric oxide production. J Immunol. 2001; 166:2173-2177. [PubMed: 11160269]

45. Sharma P, Chakraborty R, Wang L, Min B, Tremblay ML, Kawahara T, Lambeth JD, Haque SJ. Redox regulation of interleukin-4 signaling. Immunity. 2008; 29:551-564. [PubMed: 18957266]

46. Kahnert A, Seiler P, Stein M, Bandermann S, Hahnke K, Mollenkopf H, Kaufmann SH. Alternative activation deprives macrophages of a coordinated defense program to Mycobacterium tuberculosis. Eur J Immunol. 2006; 36:631-647. [PubMed: 16479545]

47. Inglis DO, Berkes CA, Hocking Murray DR, Sil A. Conidia but not yeast cells of the fungal pathogen Histoplasma capsulatum trigger a type I interferon innate immune response in murine macrophages. Infect Immun. 2010; 78:3871-3882. [PubMed: 20605974]

48. Loyd JE, Tillman BF, Atkinson JB, Des Prez RM. Mediastinal fibrosis complicating histoplasmosis. Medicine (Baltimore). 1988; 67:295-310. [PubMed: 3045478]

49. Zlotnik A, Yoshie O, Nomiyama H. The chemokine and chemokine receptor superfamilies and their molecular evolution. Genome Biol. 2006; 7:243. [PubMed: 17201934]

50. Zlotnik A, Yoshie O. Chemokines: a new classification system and their role in immunity. Immunity. 2000; 12:121-127. [PubMed: 10714678]

51. Tanaka Y, Adams DH, Hubscher S, Hirano H, Siebenlist U, Shaw S. T-cell adhesion induced by proteoglycan-immobilized cytokine MIP-1 beta. Nature. 1993; 361:79-82. [PubMed: 7678446]

52. Luther SA, Cyster JG. Chemokines as regulators of T cell differentiation. Nat Immunol. 2001; 2:102-107. [PubMed: 11175801]

53. Wong MM, Fish EN. Chemokines: attractive mediators of the immune response. Semin Immunol. 2003; 15:5-14. [PubMed: 12495636]

54. Wang J, Guan E, Roderiquez G, Norcross MA. Inhibition of CCR5 expression by IL-12 through induction of $\beta$-chemokines in human T lymphocytes. J Immunol. 1999; 163:5763-5769. [PubMed: 10570258]

55. Medeiros AI, Malheiro A, Jose PJ, Conroy DM, Williams TJ, Faccioli LH. Differential release of MIP-1 $\alpha$ and eotaxin during infection of mice by Histoplasma capsulatum or inoculation of betaglucan. Inflamm Res. 2004; 53:351-354. [PubMed: 15316665]

56. Moreira AP, Cavassani KA, Massafera Tristao FS, Campanelli AP, Martinez R, Rossi MA, Silva JS. CCR5-dependent regulatory $\mathrm{T}$ cell migration mediates fungal survival and severe immunosuppression. J Immunol. 2008; 180:3049-3056. [PubMed: 18292527]

57. Yurchenko E, Tritt M, Hay V, Shevach EM, Belkaid Y, Piccirillo CA. CCR5-dependent homing of naturally occurring $\mathrm{CD}^{+}$regulatory T cells to sites of Leishmania major infection favors pathogen persistence. J Exp Med. 2006; 203:2451-2460. [PubMed: 17015634]

58. Bystry RS, Aluvihare V, Welch KA, Kallikourdis M, Betz AG. B cells and professional APCs recruit regulatory T cells via CCL4. Nat Immunol. 2001; 2:1126-1132. [PubMed: 11702067]

59. Kroetz DN, Deepe GS Jr. An aberrant thymus in CCR5 ${ }^{-1-}$ mice is coupled with an enhanced adaptive immune response in fungal infection. J. Immunol. 2011; 186:5949-5955. [PubMed: 21478401]

60. Bettelli E, Carrier Y, Gao W, Korn T, Strom TB, Oukka M, Weiner HL, Kuchroo VK. Reciprocal developmental pathways for the generation of pathogenic effector $\mathrm{T}_{\mathrm{H}} 17$ and regulatory $\mathrm{T}$ cells. Nature. 2006; 441:235-238. [PubMed: 16648838]

61. Stritesky GL, Yeh N, Kaplan MH. IL-23 promotes maintenance but not commitment to the Th17 lineage. J Immunol. 2008; 181:5948-5955. [PubMed: 18941183]

62. Pflanz S, Timans JC, Cheung J, Rosales R, Kanzler H, Gilbert J, Hibbert L, Churakova T, Travis M, Vaisberg E, Blumenschein WM, Mattson JD, Wagner JL, To W, Zurawski S, McClanahan TK, Gorman DM, Bazan JF, de Waal Malefyt R, Rennick D, Kastelein RA. IL-27, a heterodimeric 
cytokine composed of EBI3 and p28 protein, induces proliferation of naive CD4(+) T cells. Immunity. 2002; 16:779-790. [PubMed: 12121660]

63. Devergne O, Birkenbach M, Kieff E. Epstein-Barr virus-induced gene 3 and the p35 subunit of interleukin 12 form a novel heterodimeric hematopoietin. Proc Natl Acad Sci USA. 1997; 94:12041-12046. [PubMed: 9342359]

64. Stumhofer JS, Laurence A, Wilson EH, Huang E, Tato CM, Johnson LM, Villarino AV, Huang Q, Yoshimura A, Sehy D, Saris CJ, O'Shea JJ, Hennighausen L, Ernst M, Hunter CA. Interleukin 27 negatively regulates the development of interleukin 17-producing $\mathrm{T}$ helper cells during chronic inflammation of the central nervous system. Nat Immunol. 2006; 7:937-945. [PubMed: 16906166]

65. Niedbala W, Wei XQ, Cai B, Hueber AJ, Leung BP, McInnes IB, Liew FY. IL-35 is a novel cytokine with therapeutic effects against collagen-induced arthritis through the expansion of regulatory T cells and suppression of Th17 cells. Eur J Immunol. 2007; 37:3021-3029. [PubMed: $17874423]$ 


\section{H. capsulatum is internalized by resident \& recruited phagocytes}

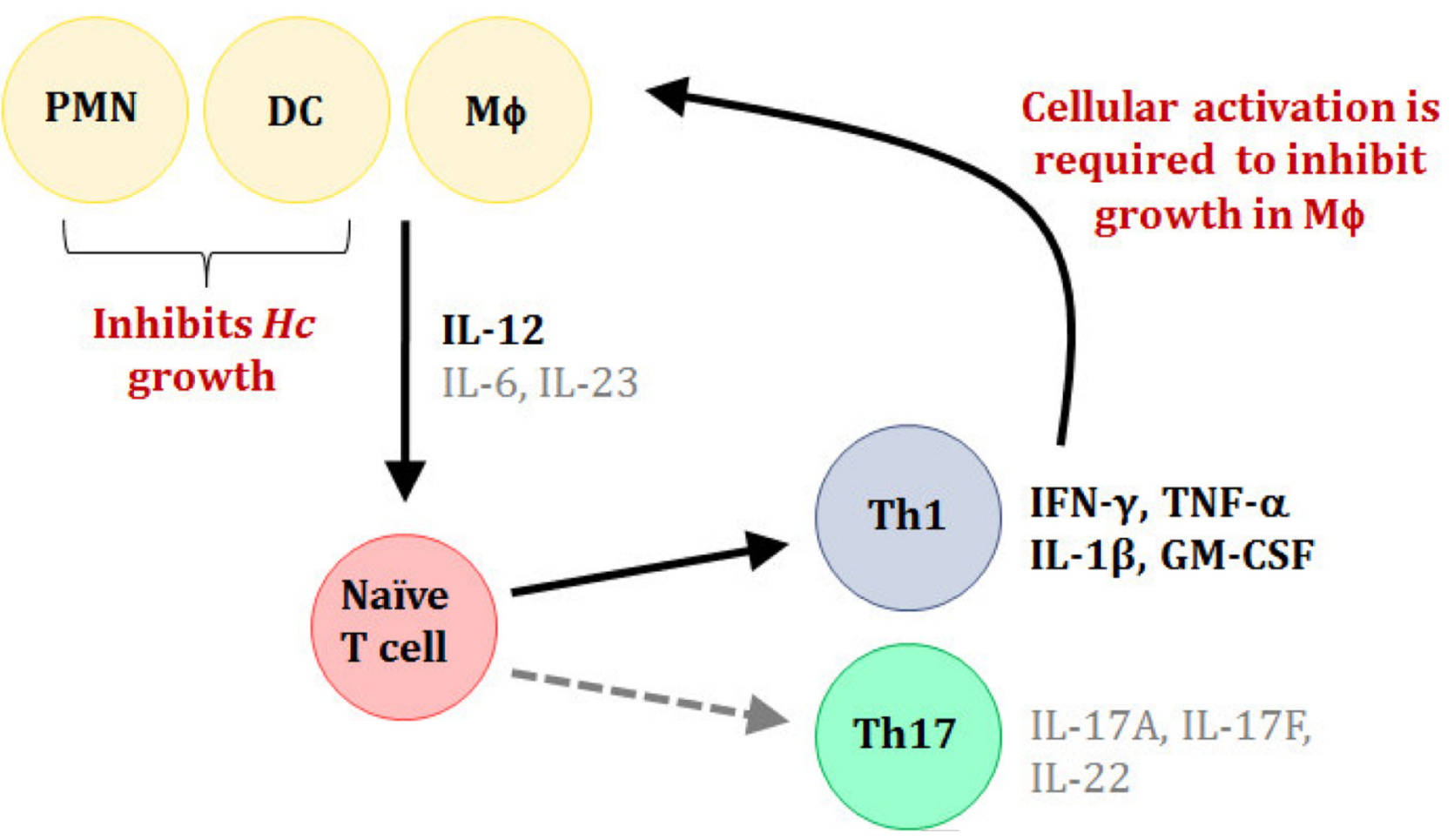

Figure 1. H. capsulatum induces a proinflammatory response Upon inhalation, the $H$. capsulatum is internalized by host phagocytes. Whereas polymorphonuclear (PMN) and DCs inhibit fungal growth, the organism replicates within $\mathrm{M} \phi$ prior to cellular activation. Cytokines such as IL-12, IL-6, and IL-23 are produced during the innate response and are involved in the polarization of naïve T cells. Th1 cells, characterized by IFN- $\gamma$, are the predominant T cell population during infection. A smaller population of Th17 population emerges, but only plays a minor role in resolving infection. In addition to IFN- $\gamma$, other Th1 cytokines including TNF- $\alpha$, IL- $1 \beta$, and GM-CSF activate $\mathrm{M} \phi$ to prevent intracellular growth. 


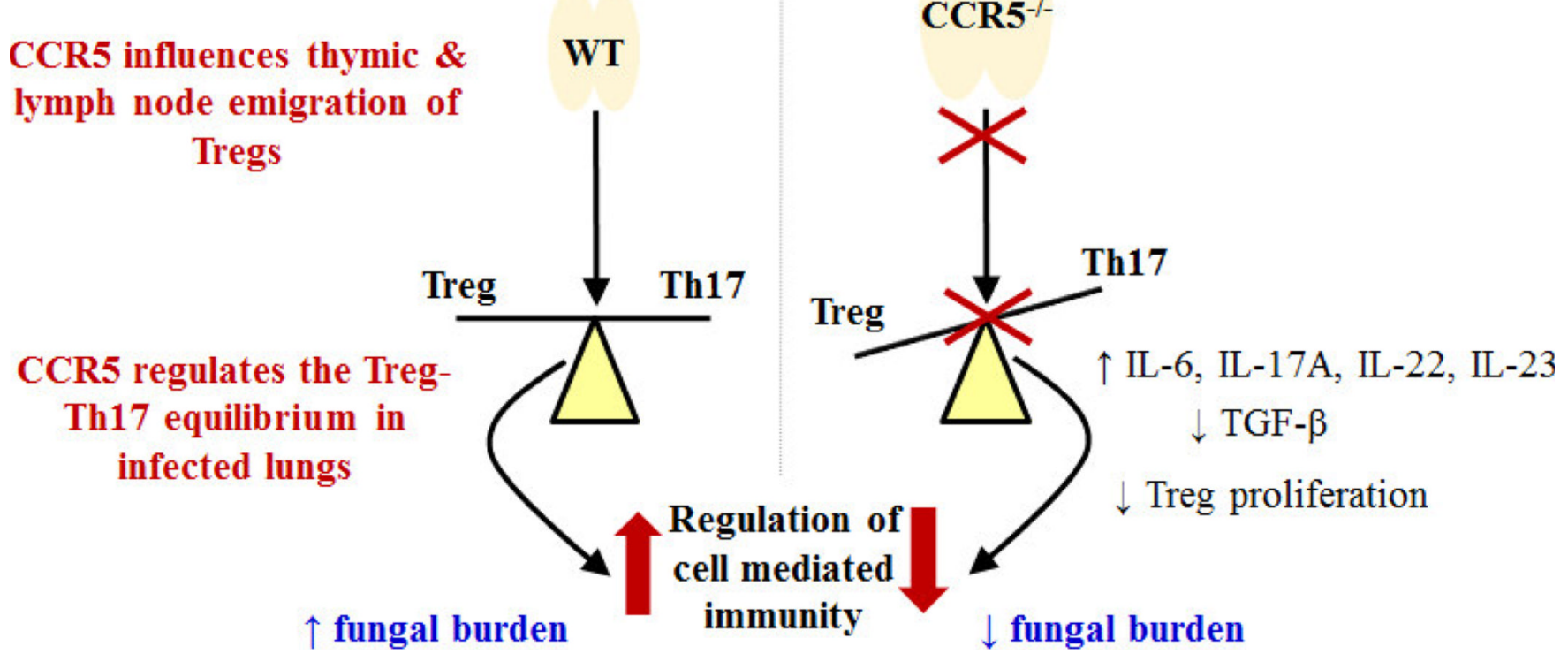

Figure 2. CCR5 mediates Treg trafficking and expansion during $\boldsymbol{H}$. capsulatum infection The absence of CCR5 results in a reduced proportion and number of Tregs in the lungs during infection. Fewer Tregs in CCR $5^{-/-}$lungs is a result of impaired trafficking and diminished proliferation. A reduction in Tregs is associated with a cytokine profile that favors a Th17 response. Thus, CCR5 functions to maintain the Treg-Th17 equilibrium to promote pathogen persistence. 